\title{
Social Media and Social skills
}

\author{
Prabhakararao Sampathirao ${ }^{1 *}$
}

\section{ABSTRACT}

Constant engagement of children with social media deprives them of face-face to face contacts and hence opportunities to practice social skills in real time situations. Technological Communication (internet and social media) preference strongly correlated with poor social skills and high social anxiety, while a greater restriction of technology in youth correlated with high social skills. One of the "benefits" advocated over and again by experts in various fields is that social media actually increases and supports the development of social skills. However, technological Communication (internet and social media) preference strongly correlated with poor social skills and high social anxiety, while a greater restriction of technology in youth correlated with high social skills in college. In this study the following five popular benefits from social media that were highlighted over and again, have been examined critically to show the reverse is true.

\section{Keywords: Social Media, Social Skill}

Human beings need to socialize as they are hardwired to fellow beings. However, connecting with others doesn't come naturally - children need to practice at development of these skills i.e., social skills, that would make them socially competent adults. Lack of good social skills can make life lonely, causing anxiety and depression. In the last two decades, advances in information technologies have substantially altered the way humans interact between email, texting, social networking, instant messaging, and Skype, people now have the resources that would make them possible to spend days or months without coming into face-to-face with another person, yet still remain connected with the world (1).

As technological communication becomes progressively diffused into our culture it results into erosion of our identities through social networking sites, it is also apparent that just as many negatives as positive outcomes are emerging. Employers are complaining about the lack of interpersonal communication skills their job applicants have, and communications skills have

\footnotetext{
${ }^{1}$ Health Education Officer, Central Health Education Bureau (Cheb) Central Health Education Bureau Kotla Road, New Delhi, India

*Responding Author

(C) 2016 I P Sampathirao; licensee IJIP. This is an Open Access Research distributed under the terms of the Creative Commons Attribution License (http://creativecommons.org/licenses/by/2.0), which permits unrestricted use, distribution, and reproduction in any Medium, provided the original work is properly cited.
} 


\section{Social Media and Social skills}

consequently been pushed to the top of the list of qualities required of employees (2). Neurological research studies have found that the brains of individuals who spend a lot of time on the Internet resemble those of drug addicts in significant ways (3). More the time members of our society spend using the computer, the less time they spend in person with family and friends (4). Other research suggests that 39\% of Americans spend more time socializing online than face-to-face (5). The American Psychiatric Association has shown clear concern with cultural tendency to spend copious hours on the Internet.

Social networking is altering the social dynamic of communication by creating the impression of a constant audience looking in on one's life and self-conscious ways on these pages to put themselves in an optimal light. The audience of "friends" that users broadcast their lives to is a list of people to whom users have given page access. The labeling of people as "friends" gives individuals the ability to publicly articulate their connections with others, verifying the reality of an audience that is constantly up to date with their own life to the automatic listener (6).Yet, the audience to whom we project our lives onto is "imagined," in that, while users have granted hundreds of people access to their page, most social networking websites do not give users a list of people who visit the page and with what frequency, this part must be imagined by the user. The imagined audience also differs from one social networking website to another. With regard to Twitter, most accounts are public, meaning that anyone can gain access to what an individual has posted. While users are given the ability to "follow" others, there is no technical requirement or social expectation of reciprocity from these followers. Therefore, the audience of followers of a Twitter user imagination is much more arbitrary than that imagined by Facebook users, who must grant permission to others to view their page. The presentation of an ideal self to an imagined audience is an example of the psychological term "self-presentation," which is the attempt to control self-relevant images before real or imagined others (7). This behavior occurs in all walks of life, as individuals learn to segregate their audiences, presenting a self-compatible to the audiences they find in different face-to-face social situations. Yet in the case of social networks, we are faced with "collapsed contexts" of multiple distinct audiences in one space and we feel pressure to present a variable self-presentation to this mixed group of people (8). Research shows that individuals who are more shy and idiocentric lie more about their identities online to appeal to an imagined audience, than extroverted individuals do (9).

We go with our friends, family members out to dinner together or to enjoy an holiday, while we “check-in” at the restaurant or hotel, impulsively someone or all of us pull out our cell phones to update our Facebook status, Instagram a picture of food, reply to a text message we just received... sometimes it seems as if we are socializing with everyone but with the person sitting right next to us. Social media and text messages become so integral to teenage life and they are

promoting anxiety and lower self -esteem. Very few of us pay attention to our teenagers' use of technology with the intensity and intimacy with which it affects their social life. 


\section{Social Media and Social skills}

There's no doubt that social media, or more specifically social networking, has radically changed the way we communicate, the opportunities and advantages for those who use it properly have exploded. However, a less positive change comes with a breakdown of interpersonal skills in young people - those we genteelly refer to as "digital natives." But at least a handful of children right from their early teens, in our neighborhood with profiles on that particular social network, and talk on the street indicate that the pre-teen set is active in other venues as well. For these children, hanging with their friends is more often a virtual activity than actually getting together in person. We've always encouraged our children to be friendly and make friends. Now, thanks to social networking, the opportunity to make friendship with hundreds of people all around the world is so simple. No one has to leave their own room, let alone do the hard work of developing deep, honest relationships (10). Much research has been done on social anxiety as a cause of over-use or addiction to technological communication, yet there has been little research done on the reverse, technological communication as a cause of social anxiety and social inadequacy. In this study the following five popular benefits from social media that were highlighted over and again, have been examined critically to show the reverse is true.

In reviewing the first benefit that social media allows kids to "break the ice" and is a low risk approach to making friends, especially for shy children, this risklessness is very risky. Learning how to make friendships is an important part of growing up, but is essentially a risky thing. There is risk in having face-to-face conversations as it takes courage to confront a friend and be honest about one's own feelings, or to deal with conflict. However, today's youth are turning to social media and texting more and more to deal with these difficult situations. Modern teens are learning to do most of their communication while looking at screen, not another person, conversation takes practice....and a dependence on devices can make it harder for children who are already struggling socially. Social skills are, in fact, skills - and skills need practice. All children need to develop these skills, but especially children who are really struggling socially. Important social skills develop from face-to-face conversations (11).

A balance needs to be found between online chatting, tweeting, video chat, and actual face-toface interactions. Some children are letting the internet take control of their social lives, and slowly the desire and ability to socialize face-to-face is decreasing. Parents can model out appropriate social skills to their children and practice with them by offering talking points and conversation starters, e.g., eye contact, handshakes, speaking slowly and clearly, how to introduce self, and general conversation manners and politeness. They can also show their children how to listen attentively and how to respond appropriately. Create opportunities for children to practice with others in their next family gathering, after school on the ride home with a friend, making small talk with the cashier at the store... again, practice helps shy children to break out of their shells a bit or give into more sociable children a chance to hone their skills. 
Regarding the second benefit that Social media leads to more intimate relationships and even improve mental and emotional health due to constant connectedness of children with friends and family, children are never really alone when it comes to social media, but learning to be alone is beneficial for their development. When they are connected or/and expected to connect, it can be emotionally draining and may lead to anxiety or even a fear of missing out if they aren't constantly connected. When get ignored online, or disconnect from those they have been constantly connected to, may lead to frustration, hurt feelings, and even depression. More the time an individual spends on the Internet at home, the less time he or she spend with friends, family members, and participating in social activities. Greater use of Internet is associated with declines in communication with family members in the household, declines in the size of the social circle, and increases in depression and loneliness. But ironically, people who are depressed, lonely, or anxious are just more likely to use social media. This is where the issue gets complicated, how social media impacts mental, emotional and social health more likely depends on how social media is being used. If the child's social media time is taking away from meaningful face-to-face time with friends and family, it's more likely to have negative impacts on health.

Additionally, health is likely to be more negatively impacted if children are passively engaging in social media (such as "lurking" or scanning other people's profiles) instead of actively engaging with the content. What for sure do we know from research is that actively engaging with friends and family members boost our mental, emotional, and social health - another reason why it is so important for our children to have face-to-face time with friends and family. Parents should help their children in setting up expectations from cell phone, Internet, and social media use as well as consequences for violating those expectations and follow through as a family. Parents also establish technology-free times or zones, such as during dinner or in the bedroom and to ensure to follow these rules for themselves as well. As the parent - if they aren't following their own rules, children won't follow them either. This will teach them that there is a time and place for technology, but that there is a need to balance it with "real-world" interaction.

Giving them the opportunity to power down and just be alone for a while during the day can help ease anxiety. If the child upsets about getting disconnected from someone (such as not getting a response to a text message right away), having a conversation with the child about how he or she is feeling, and offer an alternative activity to keep their mind off the lack of connection. Do something together to show your child that they are not alone or unloved despite being "ignored" on social media.

Before Parliament's pass any internet regulations, children who use these sites can lose sight of where their personalities finish and the outside world begins. Children's sense of identity is being eroded by "fast-paced, instant screen reactions," so that members of their generation will define themselves more by the responses of others than by their own sense of self-worth. 


\section{Social Media and Social skills}

Because of social network sites, the mid-21st century mind will be characterized by "short attention spans, sensationalism, inability to empathize and a shaky sense of identity (12). Relational aggression comes from insecurity and feeling awful about self, and wanting to put other people down so as to feel better.

Peer acceptance is a big thing for adolescents, and many of them care about their image is not less than a politician running for office,children today are getting actual polling data on how much people "like” them or their appearance and it's enough to turn anyone's head. So kids can spend hours pruning their online identities, trying to project an idealized image.Teenage girls sort through hundreds of photos, agonizing over which ones to post online. Boys compete for attention by trying to out-gross one other, pushing the envelope as much as they can in the already disinhibited atmosphere online and they gang up on each other. With the advent of social media young adults are faced with more opportunities - and more traps - than ever before. When they scroll through their feeds and see how great everyone seems, it only adds to the pressure. It is more worrisome about how the adolescents' impractical ideals that photoshopped magazine model gives, but what happens with the guy next door is also photo shopped. Even it is more confusing when one's own profile doesn't even represent the real person within himself.

The early twenties are the years in which teens are acutely aware of the contrasts between how you appear and how you "want to appear" it is similar to the 'imposter syndrome' in psychology (Dr. Wick). As you get older and acquire more mastery, you begin to realize that you are actually good at certain things, and that very feeling hopefully narrows the gap. Having your deepest and the darkest fear is that you aren't good as you look, but your inner urge to look good is really exhaustive. Self-esteem comes from consolidating who you are. The more identities you have, and the more time you spend pretending to be someone you aren't, the harder it's going to be to feel good about yourself. Girls are socialized more to compare themselves to other people to develop their identities, so it makes them more vulnerable to the downside of all thi

The conversation of children on the social media never ends, and it feels like there's always something new happening. Whatever we think of the 'relationships' maintained and in some cases initiated on social media, children never get a break from them and that, in and of itself, can produce anxiety. Everyone needs a respite from the demands of intimacy and connection, time alone to regroup, replenish and just chill out. When you don't have that, it's easy to become emotionally depleted, and it will become a fertile ground for anxiety to breed. It's also surprisingly easy to feel lonely in the middle of all that hyper connection. Taking a moment to simply take a breath and collect the thoughts can keep the mind from getting carried away with anxiety. Simply pulling back and counting to 10 during stressful situations can help to stay more calm. Practicing deep breathing techniques can help to manage stressful situations in two ways. First, if they are practiced on a regular basis, they will contribute to an overall more relaxed mood. Second, once comfortable with breathing exercises, you can access them anytime, anywhere, making them a very portable stress-reduction method. (13)

(C) The International Journal of Indian Psychology, ISSN 2348-5396 (e)| ISSN: 2349-3429 (p) | 61 


\section{Social Media and Social skills}

For one thing, children now know with depressing certainty when they're being ignored. We all have phones and we all respond to things pretty quickly, so when you're waiting for a response that doesn't come, the silence can be deafening. The silent treatment might be a strategic insult or just the unfortunate side effect of an online adolescent relationship that starts out intensely but then fades away. Children are often left imagining the worst about them, but even then the conversation doesn't end. Being in a constant state of waiting can still provoke anxiety. We can feel ourselves being put on the back burner, we put others back there, and our very human need to communicate is effectively delegated there, too.

While examining the third benefit that social media gives children the time to think about a response, think through their words before hitting "send" and sending something they might regret, instead of having to reply right away, it's very important for children and adults alike to think before they post. However, face-to-face conversations don't work like this. When someone asks a question, they expect a response right away. Children won't always have the opportunity to leave the conversation and come back when they have the perfect response. During an interview, for example, the candidate is expected to think on his feet and respond appropriately. Not being prepared for these kinds of face-to-face interactions can lead to anxiety in children. Thinking before posting also doesn't help prepare children for dealing with conflict face-to-face. They might say something that doesn't come out quickly and quite right, and they need to learn how to manage that situation (14)

In addition, social media interactions eliminate non-verbal cues that we rely on so heavily during face-to-face interactions. As a species we are very highly attuned to reading social cues. There's no question missing out on very critical social skills. In a way, texting and online communicating - it's not like it creates a nonverbal learning disability, but it puts everybody in a nonverbal disabled context, where body language, facial expression, and even the smallest kinds of vocal reactions are rendered invisible. Major part of healthy self-esteem is how to say what you think and feel right, even when you're in disagreement with other people or it feels emotionally risky (15). When those are missing it can lead to miscommunication. Children don't have the opportunity to practice picking up on these cues when they are using social media to communicate. Parents can provide opportunities with face-to-face interaction and to appraise its necessity by asking those questions that make them to think more than just a "yes or no" answer. Parents also can help them to identify nonverbal cues while having conversations e.g., meaning of a particular tone of voice that says fine, but by looking into eyes one can easily recognize the person is really worried and bothering.

But when friendship is conducted online and through texts, children are conversing in a context stripped of many of the most personal — and sometimes intimidating — aspects of communication. You aren't hearing or seeing the effect that your words are having on the other person. Because the conversation isn't happening in real time, each party can take more time to consider a 


\section{Social Media and Social skills}

response. If a child doesn't get enough practice relating to people and getting their needs met in person and in real time, many of them will grow up to be adults who are anxious about our very primary means of communication - talking. And of course social negotiations only get riskier as people get older and begin navigating romantic relationships and employment. Parents hope to teach the children to disagree without jeopardizing the relationship but, what social media is teaching them is to disagree in extreme ways and do jeopardize the relationship. It's exactly what the parents don't want to happen with their children.

Insofar as the fourth benefit that social media gives children more opportunities to communicate and practice social skills, social media provides the opportunity to develop some social skills, but not all. Those face-to-face skills lack when children spend the majority of their time communicating through devices. It's all about finding a balance between the two. Social media also limits their ability to navigate spontaneously through social interactions instead of chatting with someone on the side by; they just pull out their cell phone to avoid the conversation, putting ear/headphones ‘on' usually means that he doesn't want to talk. Children don't always have the experience as how to initiate conversations, maintain a conversation, and make "small talk." They can also become dependent on their phone or iPod to entertain them, which can diminish their self-regulation skills.

Parents can help their children to model out what it looks like an engagement in spontaneous conversation, while at the grocery store, chat with the cashier and include your child in the conversation. While riding the bus, don't pull out your phone or book - instead, sit and watch the scenery go by. Simply showing the child what it looks to be powerful, when not have to rely on technology to get through the day. Encouraging face-to-face communication as much as possible, to help balance the time spent communicating online.

The final benefit that the social media builds confidence in teens by encouraging them to connect with others: It may actually have the exact opposite effect. We know that peer acceptance is very important to adolescents. Although teens may be connecting with others in new ways, this also brings new opportunities for teens to feel either accepted or unaccepted by peers. Adolescence and the early twenties in particular are the years in which you are acutely aware of the contrasts between who you appear to be and who you think you are. An Instagram picture that only gets a few "likes" may make a child feel unaccepted by peers; a rude comment on Facebook can lower a child's self-esteem dramatically. Children start defining themselves by the responses of others instead of their own self-worth. Their confidence and self-esteem can suffer, in such situations parents should openly express their love with the children and praise them for their accomplishments. With the girls especially, refrain from complimenting them on how they look; instead, focus on their talents and inner strengths. Be open and available for conversations with the child. Let them know that parents are there with them whenever they need 


\section{Social Media and Social skills}

to talk. Discuss how their online interactions are making them feel and invite an open conversation.

\section{CONCLUSION}

If used in excess, communicating via cyberspace can inhibit communication skills, but if used in moderation, can help young people become more comfortable communicating with their peers if they are too shy to do so in person; the key is to make sure children know that real living takes place offline. (16)

\section{Acknowledgments}

The author appreciates all those who participated in the study and helped to facilitate the research process.

\section{Conflict of Interests}

The author declared no conflict of interests.

\section{REFERENCES:}

1. Are We Becoming More Socially Awkward? An Analysis of the Relationship between Technological Communication Use and Social Skills in College Students Cecilia Brown, New London, ConnecticutIs Social Media Ruining Our Children's Social Skills?- youth Service Bureau Sarah Holmboe, M.A., YSB Parent Education Coordinator.

2. McKay, J. (2005). Employers complain about communication skills. Pittsburg Postgazette.http://www.post-gazette.com/stories/business/news/employerscomplainabout- communication-skills-568960/

3. Dokoupil, T. (July, 2012). Is the web driving us mad? The Daily Beast http://www.thedailybeast.com/newsweek/2012/07/08/is-the-internet-making-uscrazywhat-the-new-research-says.html\#

4. Nie, N. H., \& Erbring, L. (2000). Internet and society: A preliminary report. Stanford Institute for the Quantitative Study of Society.)

5. Thompson, S., \& Lougheed, E. (2012). Frazzled by Facebook? An exploratory study of gender differences in social network communication among undergraduate men and women.” College Student Journal, 46, 1, 88-98.

6. Turkle, , S. (2011). Alone together: Why we expect more from technology and less from each other. New York: Basic Books.

7. Schlenker, B. (1981). Self-presentation: A conceptualization and model. Presented at the Annual Convention of the American Psychiatric Association, Los Angeles, CA. August 24-26.)

8. Goffman, E. (1961). Asylums: Essays on the social situation of mental patients and other inmates. New York: Anchor. 


\section{Social Media and Social skills}

9. Chen, B., \& Marcus, J. (2012). Students' self-presentation on Facebook: An examination of personality and self-construal factors. Computers in Human Behavior, 28, 2091 $\square 2099$. Doi: $10.1016 /$ j.chb.2012.06.013

10. How Using Social Media Affects Teenagers- Rachel Ehmke- www.childmind.org

11. Huffington Post article, and 2011

12. Relational aggression -Susan Greenfield, Professor University of Oxford.

13. How to Relax in Stressful Situations- 3 methods to calm yourself down - E.C. LaMeaux

14. Jared Pizzitola, Professional licensed counselor in psychology Today

15. The Big disconnect -Dr Gatherine Steiner Adair- clinical psychologist -

16. Pizzitola told to the online magazine NVate

How to cite this article: P Sampathirao (2016), Social Media and Social skills, International Journal of Indian Psychology, Volume 3, Issue 4, No. 57, ISSN 2348-5396 (e), ISSN: 2349-3429 (p), DIP: 18.01.026/20160304, ISBN: 978-1-365-23993-9 